\title{
Evaluation of Complications Associated with Surgically Assisted Rapid Maxillary Expansion in Cases with or Without Pterygomaxillary Disjunction
} Pterygomaksiller Ayrılmanın Olduğu Ya Da Olmadı̆̆ı̆
Olgularda Cerrahi Destekli Hızı Maksiller Genişletme ile Ilişkili
Komplikasyonların Değerlendirilmesi

\author{
(1) Burcu Gürsoytrak ${ }^{1}$, (1) Yazgı Ay Ünüvar² ${ }^{2}$ (1) Mehçure Nur Albayrak ${ }^{2}$ \\ ${ }^{1}$ Aydın Adnan Menderes University Faculty of Dentistry, Department of Oral and Maxillofacial Surgery, Aydın, Turkey \\ ${ }^{2}$ Aydın Adnan Menderes University Faculty of Dentistry, Department of Orthodontics, Aydın, Turkey
}

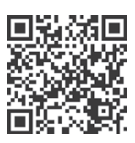

Keywords

SARME, surgery-assisted maxillary expansion complications, pterygomaxillary disjunction

Anahtar Kelimeler

SARME, cerrahi destekli maksiller genişletme komplikasyonları, pterygomaksiller ayrılma

Received/Geliş Tarihi : 22.12 .2020

Accepted/Kabul Tarihi : 13.01.2021

doi:10.4274/meandros.galenos.2021.38243

Address for Correspondence/Yazışma Adresi: Burcu Gürsoytrak MD,

Aydın Adnan Menderes University Faculty of Dentistry, Department of Oral and Maxillofacial Surgery, Aydın, Turkey Phone : +90 5055628541

E-mail :dt_burcupoyraz@hotmail.com

ORCID ID: orcid.org/0000-0002-9893-0649

(C) Meandros Medical and Dental Journal, Published by Galenos Publishing House.

This is article distributed under the terms of the Creative Commons Attribution NonCommercial 4.0 International Licence (CC BY-NC 4.0).

\begin{abstract}
Objective: Surgically assisted rapid maxillary expansion (SARME) is a widely used treatment method for the correction of transversal deficiencies of the maxilla. The gold standard treatment method among various surgical techniques has not been established. This retrospective study aimed to determine complications in SARME cases with and without pterygomaxillary disjunction and evaluate the differences between intraoperative and post-operative complications between the two groups. Materials and Methods: We enrolled 38 patients (25 females and 13 males) who underwent SARME under general anaesthesia at Aydın Adnan Menderes University Faculty of Dentistry between January 2015 and January 2020 in this study. These patients were divided into the following two groups: Patients with pterygomaxillary disjunction group and patients without pterygomaxillary disjunction group. The intraoperative and post-operative complications were evaluated for both the groups.

Results: Technically, the pterygoid junction was broken in 17 of the 38 patients included in this study with SARME; however, it was intact in 21 patients. Intraoperative haemorrhage was observed in two patients in the group with pterygomaxillary disjunction and in one patient in the group without pterygomaxillary disjunction. Electrocauterisation was performed to control bleeding in both the groups. In the group with pterygomaxillary disjunction, postoperative hematoma was observed following intraoperative haemorrhage in two patients, post-operative asymmetric expansion in two patients and post-operative unilateral transient paraesthesia in one patient.

Conclusion: The most common complication was haemorrhage, which was more observed in the group with pterygomaxillary disjunction. However, asymmetric disjunction was also seen in the group with pterygomaxillary disjunction. Whereas, minor complications were observed in the group without pterygomaxillary disjunction. As a result, the surgical technique, where the pterygoid junction remained intact, has minimal risk for complications.
\end{abstract}


Öz

Amaç: Cerrahi destekli maksiller genişletme, maksillanın transversal yön yetersizliklerinin düzeltilmesinde yaygın olarak kullanılan bir tedavi yöntemidir. Yapılan çalışmalarda bu tedavi yönteminde kullanılan farklı cerrahi tekniklerle ilgili bir altın standart bulunamamıştır. Bu retrospektif çalışmanın amacı pterygomaksiller ayrılmanın gerçekleştiği ve gerçekleşmediği cerrahi destekli hızlı üst çene genişletme olgularında görülen komplikasyonları belirlemek ve iki grup arasındaki intraoperatif ve post-operatif komplikasyon farkını değerlendirmektir.

Gereç ve Yöntemler: Aydın Adnan Menderes Üniversitesi Diş Hekimliği Fakültesi'nde Ocak 2015-0cak 2020 tarihleri arasında genel anestezi altında cerrahi destekli hızlı maksiller genişletme yapılmış tüm hastaların verileri retrospektif olarak taranmıştır. Dosyada verileri tam olan 38 adet hasta çalışmaya dahil edilmiştir. Bu hastalar pterygomaksiller ayrılma olan ve olmayan olarak iki gruba ayrılarak, bu iki grup için de intraoperatif ve post-operatif komplikasyonlar değerlendirilmiştir.

Bulgular: Çalışmaya dahil edilen 38 hastanın (25 kadın,13 erkek) 17'sinde cerrahi destekli maksiller genişletmede teknik olarak pterygoid bağlantı kırılmış, 21'inde ise pterygoid bağlantı kırılmamıştı. Pterygoid ayrılan grupta 2 hastada, pterygoid ayrılmayan grupta ise 1 hastada intraoperatif hemoraji geliştiği görüldü. Her iki grupta da kanama kontrolü için elektrokoterizasyon kullanılmıştı. Pterygoid ayrılan grupta 2 hastada intraoperatif hemorajiyi takiben postoperatif hematom, 2 hastada post-operatif asimetrik ekspansiyon ve 1 hastada post-operatif tek taraflı geçici parestezi görüldü.

Sonuç: En sık karşılaşılan komplikasyon hemorajiydi ve bu da pterygoid bağlantının ayrıldığı grupta daha sık gözlendi. Yine asimetrik ayrılma da pterygoid bağlantının ayrıldığı grupta görüldü. Pterygoid bağlantının ayrılmadığı grupta minör komplikasyonlar gözlendi. Sonuç olarak pterygoid bağlantının kırılmadığı cerrahi teknik komplikasyon açısından daha az risklidir.

\section{Introduction}

Maxillary expansion is an orthodontic treatment that is widely used to correct transversal deficiencies maxilla (1). When this expansion method is applied in a patient with skeletal maturity; undesirable effects such as lateral tipping of posterior teeth, extrusion, periodontal membrane compression, bending of the alveolar bone, buccal cortex fenestration, palatal tissue necrosis, failure to open the midpalatal suture, pain and instability in maxillary expansion (2). As attempts to orthopedically change the transversal size of the maxilla with advancing age cause more complications, surgical procedures have been recommended to facilitate correction of transversal discrepancies.

The purpose of surgically assisted rapid maxillary expansion (SARME); is to provide skeletal expansion instead of dental enlargement and to minimize dental tipping by separating the midpalatal and lateral maxillary sutures (3). SARME; is preferred in patients with skeletal maturity and having maxillary transversal insufficiency more than $5 \mathrm{~mm}$.

In early studies, midpalatal suture was defined as the area of greatest resistance to maxillary expansion (4-6). It is advocated in some publications that it is required to avoid pterygomaxillary disjunction (PMD) to make the surgery less invasive (7). However, subsequent reports highlight that the zygomatic buttress and pterygomaxillary junction are areas of critical resistance (2,8-10). However, depending on the area where maxilla expansion is desired, it may be necessary to disconnect the maxilla from the pterygoid plates during the SARME operation. When osteotomy is not performed in this area, which is one of the most important points of resistance, the posterior nasal spina acts as a rotation center due to the resistance in the pterygomaxillary junction and while the enlargement is seen more in the anterior of the maxilla, and less in the posterior (11).

Although SARME is considered a safe and simple procedure, its complication rate remains uncertain. Researches published in the literature report variable results along with complications in $1 \%$ to $50 \%$ of the cases $(3,12,13)$. Researches that found high complication rates divided the complications into minor and major. Major complications are those associated with high morbidity, risk of death or permanent sequellae. Minor complications do not cause sequellae and require simple outpatient treatment (3,13-16). In addition to surgical complications, some orthodontic complications such as asymmetric maxillary expansion or tooth extrusion are frequently identified (17-19).

Despite the application of new techniques, the incidence of complications and the types of complications associated with each technique remain uncertain. In this research, complications developed in SARME cases with and without PMD were determined, and the difference in complications during or after 
surgery between cases with and without PMD was evaluated.

\section{Materials and Methods}

All patients, who underwent SARME surgery under General Anesthesia at Aydın Adnan Menderes University Faculty of Dentistry between January 2015 and January 2020, were retrospectively scanned. Ethical approval was obtained from Aydın Adnan Menderes University Faculty of Dentistry Clinical Research Ethics Committee (protocol no: 2020/01, date: 05.08.2020). The protocol was conducted in accordance with the guidelines of the World Medical Association Declaration of Helsinki. All patients reviewed and signed written informed consent forms.

Thirty-eight patients, who met the inclusion criteria, were grouped as with and without PMD during corticotomy. The same surgical team used the same techniques in each group. The orthodontist cemented the fixed hyrax type expansion appliance 1-2 days before surgery. Inclusion criteria for this research; are the cases which have completed skeletal development, in which bilateral maxillary stenosis is greater than $5 \mathrm{~mm}$, which has good oral hygiene and healthy periodontal tissue. The presence of one of the maxillary sinus diseases and those with previous maxillomandibular intervention were not included in the study. Intraoperative and post-operative 6-month complications were evaluated in the group with and without PMD. Complication data collected for each patient during and after surgery for 6 months in both groups were analyzed. Prediction variables include demographic parameters (age and gender).

\section{Surgical Technique}

A standard surgical technique applied under general anesthesia in the operating room was used in all cases. Local anesthesia was routinely applied for hemostasis before incision. A full-thickness maxillary vestibular incision was made bilaterally extending from the first molar mesial to the distal of the ipsilateral canine tooth and subperiosteal dissection was completed to show the maxilla from the piriform rim to the buttress. The flap is elevated atraumatically and minimally to prevent possible tissue necrosis in the anterior region of maxilla in the planned interdental osteotomy site (usually midline). Osteotomy in Le Fort I level was performed using a straight fissure drill. In addition, in the group where
PMD occurs, pterydoid plates are disconnected with the help of osteotome. The Hyrax appliance was activated to see the independent movement of two segments of maxilla and later it was deactivated and the flap was repositioned and sutured.

\section{Statistical Analysis}

Statistical analysis was made by using Statistical Package for Social Sciences software package (for Windows 98, version 10.0; SPSS, Chicago, IL, USA). All data given were calculated by descriptive statistics method over numbers and percentages.

\section{Results}

Of the 38 patients included in the research, 25 of them were female and 13 of them were male. In 17 of 38 patients, SARME was done with PMD, and in 21 patients without PMD.

Considering the total number of patients included, the gender distribution was higher for women, with $65.78 \%$ female and $34.22 \%$ male.

Intraoperative hemorrhage was observed in 2 patients in the with PMD group and 1 patient in the without PMD group. Electrocauterization was used to control bleeding in both groups. In the with PMD group, post-operative hematoma was observed in 2 patients following intraoperative hemorrhage, post-operative asymmetric expansion in 2 patients, and post-operative unilateral transient paresthesia in 1 patient likewise. In the without PMD group, 1 patient developed epistaxis on the post-operative $1^{\text {st }}$ day after intraoperative hemorrhage. No laceration, sinus infection, permanent nerve damage, dental or periodontal problems were encountered in any patient. When the complication reports were discussed individually, while the rate of complications in women was $18.18 \%$ in the with PMD group and $7.14 \%$ in the without PMD group, it is $33.33 \%$ in the with PMD group and 14.28 in the without PMD group. The post-operative follow-up period of these patients was 6 months.

When the patients were evaluated in terms of age, the age distribution was between 15-31, the average age was 19.68. For the with PMD group, while the mean age with complications was 24.25 and the mean age without complications was 21.07, as for the without PMD group, the mean age with complications was 21.5 , and the mean age without complications was 17.55 . By looking at both groups, 
the average age was found to be higher in the groups with complications.

\section{Discussion}

Although SARME is a frequently used treatment in the treatment of transversal maxillary constriction, post-operative complications such as pain, bleeding, infection, sinusitis, dental and periodontal problems, palatal mucosa ulceration, asymmetric expansion, recurrence, aseptic necrosis, orbital complications can be seen, but there is not a clear information about the incidence of complications (3). It was reported that SARME had lower morbidity while being compared to other orthognathic surgical procedures (20). The development of a nasopalatine duct cyst, bilateral lingual anesthesia and orbital compartment syndrome, have also been reported among some unusual complications (2). There are also publications that mention complications related to expansion device (21).

PMD is still a controversial subject in the literature. Some authors support PMD by suggesting that the pterygomaxillary buttress creates an area of resistance in expansion and that without PMD increases the likelihood of erroneous expansion. However, another controversial issue is the increasing surgical complications when PMD is performed $(16,22,23)$. There are also publications that mention making surgery non-invasive by avoiding PMD. The study is a multidisciplinary topic as it concerns both oral and maxillofacial surgeons and orthodontists.

Timms and Vero (4) reported in their research that those over 25 years of age are appropriate for SARME. While Mommaerts (24) is recommending non-surgical maxillary expansion in patients younger than 12 years of age, he suggested that corticotomy is essential to release points of resistance for those over 14 years of age. Epker and Wolford (25) suggest SARME in patients over the age of 16 . Our research had findings compatible with these studies. The patients we applied SARME were between the ages of 15-31 and the average age was 19.68.

It is thought that PMD performed by using an osteotome can trigger post-operative vascular events. In cases of upper jaw fractures, other factors such as a pseudoaneurysm, a high-level pterygoid plate fracture, late wound infection, and injuries to the sphenopalatine and descending palatine arteries during advanced maxillary mobilization can trigger life-threatening hemorrhage. However, SARME causes much lower morbidity in particular compared to down fracture of the maxilla in Le Fort (14). In the large SARME case series by Politis (26) (376 patients), no life-threatening haemorrhage was noted. In this research, it was seen that post-operative hematoma developed following intraoperative hemorrhage in 2 patients in the with PMD group, and intraoperative hemorrhage developed in 1 patient in the without PMD group. Electrocauterization was used to control bleeding in both groups.

Epistaxis is a frequently reported complication as a possible result of surgical damage to soft tissues around the maxillary sinus and nasal cavity (12-14). When epistaxis develops, it is easily treated with compression and nasal buffering. Dergin et al. (12) when evaluating the complications after SARME retrospectively, they reported that $20 \%$ of all patients developed epistaxis. On the other hand, Mehra et al. (27) reported a life-threatening case of delayed epistaxis after SARME. In our research, an epistaxis developed in one patient (2.63\%) in the without PMD group on the day following surgery. Hemostasis was achieved with an anterior nasal buffering. Since PMD was not performed in this patient, the probable cause of bleeding is traumatic osteotomy of the lateral nasal wall.

It was reported that changes in blood flow and damage to the branches of the maxillary nerve caused paresthesia in the infraorbital region and lips, and numbness in the teeth (13). Subjective changes in gingival numbness somatosensorial function, and cutaneous numbness in the face and palate have also been reported in the literature $(28,29)$. One of the patients in the PMD group reported transient unilateral mild facial paresthesia possibly related to trauma to the infraorbital nerve by tissue retractors and temporary unilateral numbness of the gums. All the numbness ameliorated 6 months after the operation.

Asymmetric expansion seen after SARME; is the main complication whose prevalence has been reported in a wide variation from $3.4 \%$ to $18 \%$ (3034). Asymmetrical or uneven expansion may be due to slow activation rate or PMD deficiency. Verlinden et al. (31) reported in their research that asymmetric expansion developed in 5 of the 73 cases and that all 
cases with asymmetric expansion required additional surgery. Seitz et al. (32) reported in their study that asymmetric expansion was the most common surgical complication in a group of 22 patients. Koudstaal et al. $(34,35)$ recorded asymmetric expansion in 2 of 46 patients and 4 out of 10 heads, and concluded that the potential problem was retention in the pterygomaxillary junction. They thought that although PMD was done, asymmetrical movement occurred in the maxillary segments as a result of the incomplete fracture on one side. In this research, asymmetric expansion was observed totally in 2 patients, 1 patient apiece in both groups. The same expansion appliance and the same RME protocol were applied to all patients evaluated in our research. As the slow expansion protocol was not applied, asymmetric expansion was not formed depending on the RME protocol. Carvalho et al. (36) suggested that the slow expansion protocol might be associated with asymmetric expansion complication due to early callus formation. Like other researchers, we think that the occurring of asymmetric expansion despite the PMD is due to the absence of complete disjunction on one side. $(34,35)$. No extra surgery was applied on these patients. It was observed that dental transversal were compensated.

\section{Conclusion}

As a result of this research, the most common complication was hemorrhage and it was observed more frequently in the with PMD group. Major complications were not observed in any group. In conclusion, we think that surgical technique without pterygoid disjunction, is less risky in terms of complications. However, additional prospective and long-term follow-up researches with more cases are needed to clarify individual factors that may cause complications.

\section{Ethics}

Ethics Committee Approval: Ethical approval was obtained from Aydın Adnan Menderes University Faculty of Dentistry Clinical Research Ethics Committee (protocol no: 2020/01, date: 05.08.2020). The protocol was conducted in accordance with the guidelines of the World Medical Association Declaration of Helsinki.

Informed Consent: All patients reviewed and signed written informed consent forms.
Peer-review: Externally and internally peerreviewed.

\section{Authorship Contributions}

Concept: B.G., Design: B.G., Y.A.Ü., Supervision: B.G., Materials: M.N.A., Data Collection or Processing: M.N.A., Analysis or Interpretation: M.N.A., B.G., Literature Search: M.N.A., Critical Review: Y.A.Ü., Writing: B.G., Y.A.Ü.

Conflict of Interest: No conflict of interest was declared by the authors.

Financial Disclosure: The authors declared that this study received no financial support.

\section{References}

1. Marshall SD, Southard KA, Southard TE, editors. Early transverse treatment. Semin Orthod 2005; 11: 130-9.

2. Suri L, Taneja P. Surgically assisted rapid palatal expansion: a literature review. Am J Orthod Dentofacial Orthop 2008; 133: 290-302.

3. Williams BJ, Currimbhoy S, Silva A, O'Ryan FS. Complications following surgically assisted rapid palatal expansion: a retrospective cohort study. J Oral Maxillofac Surg 2012; 70: 2394-402.

4. Timms DJ, Vero D. The relationship of rapid maxillary expansion to surgery with special reference to midpalatal synostosis. $\mathrm{Br} \mathrm{J}$ Oral Surg 1981; 19: 180-96.

5. Melsen B. Palatal growth studied on human autopsy material. A histologic microradiographic study. Am J Orthod 1975; 68: 42-54.

6. Persson $\mathrm{M}$, Thilander $\mathrm{B}$. Palatal suture closure in man from 15 to 35 years of age. Am J Orthod 1977; 72: 42-52.

7. Dolanmaz D, Esen A, Emlik D, Candirli C, Kalayci A, Ciçekcibaşi A. Comparison of two different approaches to the pterygomaxillary junction in Le Fort I osteotomy. Oral Surg Oral Med Oral Pathol Oral Radiol Endod 2008; 106: 1-5.

8. Lines PA. Adult rapid maxillary expansion with corticotomy. Am J Orthod 1975; 67: 44-56.

9. Bell WH, Jacobs JD. Surgical-orthodontic correction of horizontal maxillary deficiency. J Oral Surg 1979; 37: 897-902.

10. Kennedy JW 3rd, Bell WH, Kimbrough OL, James WB. Osteotomy as an adjunct to rapid maxillary expansion. Am J Orthod 1976; 70: 123-37.

11. Liou EJ. Effective maxillary orthopedic protraction for growing Class III patients: a clinical application simulates distraction osteogenesis. Prog Orthod 2005; 6: 154-71.

12. Dergin G, Aktop S, Varol A, Ugurlu F, Garip H. Complications related to surgically assisted rapid palatal expansion. Oral Surg Oral Med Oral Pathol Oral Radiol 2015; 119: 601-7.

13. Verquin $M$, Daems $L$, Politis $C$. Short-term complications after surgically assisted rapid palatal expansion: a retrospective cohort study. Int J Oral Maxillofac Surg 2017; 46: 303-8.

14. Cakarer S, Keskin B, Isler SC, Cansiz E, Uzun A, Keskin C. Complications associated with surgically assisted rapid palatal 
expansion without pterygomaxillary separation. J Stomatol Oral Maxillofac Surg 2017; 118: 279-82.

15. Hamedi Sangsari A, Sadr-Eshkevari P, Al-Dam A, Friedrich RE, Freymiller E, Rashad A. Surgically Assisted Rapid Palatomaxillary Expansion With or Without Pterygomaxillary Disjunction: A Systematic Review and Meta-Analysis. J Oral Maxillofac Surg 2016; 74: 338-48.

16. Hernandez-Alfaro F, Bueno JM, Diaz A, Pagés CM. Minimally invasive surgically assisted rapid palatal expansion with limited approach under sedation: a report of 283 consecutive cases. J Oral Maxillofac Surg 2010; 68: 2154-8.

17. Algharbi M, Bazargani F, Dimberg L. Do different maxillary expansion appliances influence the outcomes of the treatment? Eur J Orthod 2018; 40: 97-106.

18. Pereira MD, Koga AF, Prado GPR, Ferreira LM. Complications From Surgically Assisted Rapid Maxillary Expansion With HAAS and HYRAX Expanders. J Craniofac Surg 2018; 29: 275-8.

19. Moura LB, Spin-Neto R, Sverzut CE, Monnazzi MDS, Trivellato $A E$, Gabrielli MAC, et al. Evaluation of the palatal split pattern in surgically rapid maxillary expansion-comparison of two techniques. Oral Maxillofac Surg 2016; 20: 255-8.

20. Bays RA, Greco JM. Surgically assisted rapid palatal expansion: an outpatient technique with long-term stability. J Oral Maxillofac Surg 1992; 50: 110-3.

21. Humber CC, Lanigan DT, Hohn FI. Retrograde hemorrhage (hemolacria) from the lacrimal puncta after a Le Fort I osteotomy: a report of 2 cases and a review of the literature. J Oral Maxillofac Surg 2011; 69: 520-7.

22. Zandi M, Miresmaeili A, Heidari A, Lamei A. The necessity of pterygomaxillary disjunction in surgically assisted rapid maxillary expansion: A short-term, double-blind, historical controlled clinical trial. J Craniomaxillofac Surg 2016; 44: 1181-6.

23. Júnior SML, de Moraes M, Asprino L. Photoelastic analysis of stress distribution of surgically assisted rapid maxillary expansion with and without separation of the pterygomaxillary suture. J Oral Maxillofac Surg 2011; 69: 1771-5.

24. Mommaerts MY. Transpalatal distraction as a method of maxillary expansion. Br J Oral Maxillofac Surg 1999; 37: 268-72.

25. Fish LC, Epker BN. Dentofacial deformities related to midface deficiencies. Integrated orthodontic-surgical correction. J Clin Orthod 1987; 21:654-64.
26. Politis C. Life-threatening haemorrhage after 750 Le Fort I osteotomies and 376 SARPE procedures. Int J Oral Maxillofac Surg 2012; 41:702-8.

27. Mehra P, Cottrell DA, Caiazzo A, Lincoln R. Life-threatening, delayed epistaxis after surgically assisted rapid palatal expansion: a case report. J Oral Maxillofac Surg 1999; 57: 201-4.

28. Thygesen TH, Bardow A, Norholt SE, Jensen J, Svensson P. Surgical risk factors and maxillary nerve function after Le Fort I osteotomy. J Oral Maxillofac Surg 2009; 67: 528-36.

29. Jędrzejewski M, Smektała T, Sporniak-Tutak K, Olszewski R. Preoperative, intraoperative, and postoperative complications in orthognathic surgery: a systematic review. Clin Oral Investig 2015; 19: 969-77.

30. Ramieri GA, Spada MC, Austa M, Bianchi SD, Berrone S. Transverse maxillary distraction with a bone-anchored appliance: dentoperiodontal effects and clinical and radiological results. Int J Oral Maxillofac Surg 2005; 34: 357-63.

31. Verlinden CR, Gooris PG, Becking AG. Complications in transpalatal distraction osteogenesis: a retrospective clinical study. J Oral Maxillofac Surg 2011; 69: 899-905.

32. Seitz O, Landes CA, Philipp DJ, Sader R, Klein CM. Reliable surgically assisted rapid palatal expansion by maxillary widening device. J Craniofac Surg 2008; 19: 846-9.

33. Verstraaten J, Kuijpers-Jagtman AM, Mommaerts MY, Bergé SJ, Nada RM, Schols JG, et al. A systematic review of the effects of bone-borne surgical assisted rapid maxillary expansion. J Craniomaxillofac Surg 2010; 38: 166-74.

34. Koudstaal MJ, Wolvius EB, Schulten AJ, Hop WC, van der Wal KG. Stability, tipping and relapse of bone-borne versus tooth-borne surgically assisted rapid maxillary expansion; a prospective randomized patient trial. Int J Oral Maxillofac Surg 2009; 38: 308-15.

35. Koudstaal MJ, Smeets JB, Kleinrensink GJ, Schulten AJ, van der Wal KG. Relapse and stability of surgically assisted rapid maxillary expansion: an anatomic biomechanical study. J Oral Maxillofac Surg 2009; 67: 10-4.

36. Carvalho PHA, Moura LB, Trento GS, Holzinger D, Gabrielli MAC, Gabrielli MFR, et al. Surgically assisted rapid maxillary expansion: a systematic review of complications. Int J Oral Maxillofac Surg 2020; 49: 325-32. 